\section{Michigan Technological \\ 18 : University}

Michigan Technological University Digital Commons @ Michigan Tech

\title{
The Effects of Dispatch Strategy on Electrical Performance of Amorphous Silicon-based Solar Photovoltaic-thermal Systems
}

Joseph Rozario

Michigan Technological University

A. H. Vora

Michigan Technological University

S. K. Debnath

Michigan Technological University

M. Pathak

Queen's University - Kingston, Ontario

Joshua M. Pearce

Michigan Technological University

Follow this and additional works at: https://digitalcommons.mtu.edu/materials_fp

\section{Recommended Citation}

J. Rozario, A.H. Vora, S.K. Debnath, M.J.M. Pathak, J.M. Pearce, The effects of dispatch strategy on electrical performance of amorphous silicon-based solar photovoltaic-thermal systems, Renewable Energy, 68, pp. 459-465 (2014). http://digitalcommons.mtu.edu/materials_fp/46 
J. Rozario, A.H. Vora, S.K. Debnath, M.J.M. Pathak, J.M. Pearce, The effects of dispatch strategy on electrical performance of amorphous silicon-based solar photovoltaic-thermal systems, Renewable Energy 68, pp. 459-465 (2014). http://dx.doi.org/10.1016/j.renene.2014.02.029

\title{
The effects of dispatch strategy on electrical performance of amorphous silicon-based solar photovoltaic-thermal systems
}

\author{
J. Rozario $^{1}$, A.H. Vora ${ }^{1}$, S.K. Debnath ${ }^{1}$, M.J.M. Pathak ${ }^{2}$, and J. M. Pearce ${ }^{1,3}$ \\ 1. Department of Electrical \& Computer Engineering, Michigan Technological \\ University, Houghton, Michigan, USA 49931 \\ 2. Department of Mechanical and Materials Engineering, Queen's University, Kingston, \\ Ontario, Canada K7L 3N6 \\ 3. Department of Materials Science \& Engineering, Michigan Technological University \\ Houghton, Michigan, USA 49931
}

\begin{abstract}
:
Previous work has shown that high-temperature short-term spike thermal annealing of hydrogenated amorphous silicon (a-Si:H) photovoltaic thermal (PVT) systems results in higher electrical energy output. The relationship between temperature and performance of a-Si:H PVT is not simple as high temperatures during thermal annealing improves the immediate electrical performance following an anneal, but during the anneal it creates a marked drop in electrical performance. In addition, the power generation of a-Si:H PVT depends on both the environmental conditions and the Staebler-Wronski Effect kinetics. In order to improve the performance of a-Si:H PVT systems further, this paper reports on the effect of various dispatch strategies on system electrical performance. Utilizing experimental results from thermal annealing, an annealing model simulation for a-Si:H-based PVT was developed and applied to different cities in the U. S. to investigate potential geographic effects on the dispatch optimization of the overall electrical PVT systems performance and annual electrical yield. The results showed that spike thermal annealing once per day maximized the improved electrical energy generation.
\end{abstract}

Keywords: Hydrogenated amorphous silicon; a-Si; thermal annealing; photovoltaic thermal hybrid system (PVT or PV/T)

\section{Introduction}

Despite improvements in solar photovoltaic (PV) efficiency, which reduces the cost of PV generated electricity to competitive levels in some markets [1], in conventional cells much of the radiation above the bandgap does not contribute to electrical energy generation and instead is wasted as heat. On the other hand, solar thermal systems, which have the potential for high efficiencies, have low exergy values [2]. Thus, developing photovoltaic solar thermal (PVT) systems offer a distinct advantage over simple PV or low exergy solar thermal systems by utilizing this waste thermal energy from the PV absorber for heating applications [2]. PVT offers advantages in overall exergy, energy and cost [2-9]. Historically, most of the PVT systems were developed using crystalline silicon (c-Si) PV, which have a thermal coefficient of $-0.45 \% / \mathrm{K}$ [10]. Because of this relatively large thermal coefficient c-Si-based PVT systems are designed to cool the c-Si PV modules in order to maximize the electrical output and extracted thermal energy is considered as secondary benefit. This results in non-optimization of c-Si-based PVT systems because the thermal component under-performs when compared to standard solar thermal collectors [11-15].

Thin-film hydrogenated amorphous silicon (a-Si:H) solar cells, however, have a thermal coefficient of only $-0.13 \% / \mathrm{K}[10]$, which makes it suitable for high temperature applications that are not possible with c-Si PV due to what would be significant electrical output losses at high operating temperatures. The biggest technical challenge confronting a-Si:H PV is a light-induced 
degradation of performance known as the Staebler-Wronski effect (SWE)[16-20]. This effect is associated with the creation of defect states in the a-Si:H material when exposed to sunlight, which causes a reduction in efficiency of the solar cells with exposure time [17]. These defects states tend to saturate after an extended exposure to sunlight (approximately 100 hours under continuous 1 sun illumination) and this stabilized state is refereed as degraded steady-state (DSS) [21-22]. However, it has been found that SWE is reversible in nature and the performance (efficiency) of a-Si:H solar cell can be returned to its initial state if the cell is heated to $150{ }^{\circ} \mathrm{C}$ for 4 hours as the defect states are annealed [17, 21, 23, 24] although the defect states can anneal at lower temperatures over more extended time periods [21]. Reducing SWE is viewed as so important, that Pola et al. have even suggested removing entire PV arrays and annealing the modules in a hot air oven at lower temperatures (e.g. at $80^{\circ} \mathrm{C}$ ) over extended times [25]. Additionally, because of this effect it has been reported that a-Si:H PV performs better at high temperatures in view of the fact that optoelectronic properties of a-Si:H materials [26-28] stabilize at a higher efficiency at higher temperatures [22,29]. Operating at elevated temperatures is highly desirable for PVT hybrid systems as the solar thermal efficiency increases with temperature. For a solar thermal flat plate collector a temperature of $100^{\circ} \mathrm{C}$ can be easily achieved and if the system is stagnated it can even climb higher than $200^{\circ} \mathrm{C}$ [30]. Therefore, direct deposition of a-Si:H PV over flat plate solar collectors can facilitate high-temperature operation where the PV panel could be in-situ annealed and simultaneously increasing overall system exergy [31-33]. It has also been experimentally demonstrated that high temperature operation and regular high temperature spike thermal annealing for $1 \mathrm{~h}$ at $100^{\circ} \mathrm{C}$ on a $12 \mathrm{~h}$ cycle can result in higher energy and exergy output [34]. However, a dispatch strategy is required to optimize the usage of available resources to meet the electrical and thermal demand and to maximize the overall system efficiency. Although spike thermal annealing of a-Si:H PV panels with short thermal spikes can improve the immediate electrical performance following an anneal, the annealing process at high temperatures creates a marked drop in electrical performance over the annealing period (it can also deteriorate the overall thermal performance of the system as the thermal energy required for spike annealing is not being extracted). It has also been observed that, the degraded steady state is obtained more rapidly at higher temperature at a higher power [34]. Therefore a dispatch strategy is required to optimize the number of required spike thermal annealing cycles in order to maximize the overall system performance including the thermal and electrical output.

This paper reports on the effects of various dispatch strategies on the first of these outputs - the electrical system performance. Utilizing experimental results from thermal annealing, an annealing model simulation for a-Si:H-based PVT was developed and applied to different cities (Goldendale, San Antonio, Reno and Las Vegas) in U.S. to investigate the effects of geographic optimization on the overall electrical PVT systems performance.

\section{Methods}

The PVT system shown schematically in Figure 1 was used for modeling and simulation in this paper. The a-Si:H PV is connected to an inverter that powers the AC load and the heat generated by the PVT is transferred to thermal load by a heat exchanger. A temperature controller is used to control both this heat flow and the regular thermal annealing, which is provided by the heat generated from the PVT itself. High temperature spike thermal annealing 
for 1 hour at $100{ }^{\circ} \mathrm{C}$ at regular cycles is carried in order to reverse SWE.

Usually a-Si:H-based PV exhibit power degradation due to 1) the temperature effect, exhibited by all solar cells and 2) SWE, which is a long-term light exposure effect, which is a unique characteristic of a-Si:H-based solar cells. The total energy generated by the PV of power, $P$, for a year is given by:

$E=\sum_{n=1}^{365 \times 24} P_{n} \cdot t$

where, $P_{n}$ is the power produced in the $n^{\text {th }}$ hour and $t$ is time, which is 1 hour is this case. The

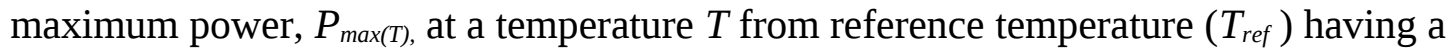
temperature coefficient of $\gamma$ is given by [35]:

$P_{\max (T)}=\frac{P_{\max (r \varepsilon f)}}{\left(1+\gamma \cdot\left(T_{r \varepsilon f}-T\right)\right)} \cdot \frac{S}{S_{r \varepsilon f}} \cdot \frac{1}{\left(1+\delta \ln \left(\frac{S}{S_{r \varepsilon f}}\right)\right)}$

where $S$ and $S_{\text {ref }}$ are the irradiance and reference irradiance level respectively, $P_{\max (r e f)}$ is the maximum power at a reference temperature $T_{\text {ref }}$, which is $25^{\circ} \mathrm{C}, S_{\text {ref }}$ is equal to $1000 \mathrm{~W} / \mathrm{m}^{2}, \gamma$ is $-0.0020 /{ }^{\circ} \mathrm{C}, \delta$ is +0.063 [35]. Equation (2) is used to calculate the power with no thermal annealing and universally applicable to any solar cells.

Equation (2) does not take SWE into account and must therefore be modified with an exponential term that is governed by the aggregate exposure to solar flux from the annealed state and the operating temperature. The exponential terms were determined by curve fitting the experimental results of Pathak et al. [34] as shown in Figure 2.

Figure 2 shows the experimentally obtained data for degenerated steady states at different temperatures for a-Si:H based PV/T with i-layer thickness of $630 \mathrm{~nm}$ under 1 sun $\left(1000 \mathrm{~W} / \mathrm{m}^{2}\right.$ irradiance ) for 600 hours. For a-Si:H PVT the modified form of equation (2) is altered to be:

$P_{\max (T)}=\left(\frac{P_{\max (r \varepsilon f)}}{\left(1+\gamma\left(T_{r \varepsilon f}-T\right)\right)}-k_{d s s} P_{\max (r \varepsilon f)} \cdot\left(1-e^{\left.-u_{d s s \cdot t}\right)}\right) \cdot \frac{s}{S_{r \ell f}} \cdot \frac{1}{\left(1+\delta \ln \left(\frac{S_{r \varepsilon f}}{S}\right)\right)}\right.$

The values of the parameters $k_{d s s}$ and $u_{d s s}$ were obtained by analyzing the experimental data and their values vary with temperature. For the temperatures $25^{\circ} \mathrm{C}, 50^{\circ} \mathrm{C}$, and $90^{\circ} \mathrm{C}, k_{d s s}$ has the values $0.3450,0.2154$, and 0.07917 respectively; and $u_{\text {dss }}$ has the values $0.03601,0.07552$ and 0.2097 
J. Rozario, A.H. Vora, S.K. Debnath, M.J.M. Pathak, J.M. Pearce, The effects of dispatch strategy on electrical performance of amorphous silicon-based solar photovoltaic-thermal systems, Renewable Energy 68, pp. 459-465 (2014). http://dx.doi.org/10.1016/j.renene.2014.02.029

respectively as determined from Figure 2. It should be noted that as the temperature rises $k_{d s s}$ decreases and $u_{d s s}$ increases, as is consistent with prior SWE studies of a-Si:H PV [36-38].

During annealing the temperature rises rapidly from normal operating temperature to high temperature $\left(\sim 100^{\circ} \mathrm{C}\right)$ for a short duration (1 hour) and this reduces electrical performance. The power drops rapidly as the temperature is increased for the anneal and then starts to rise slowly as the annealing continues. For simplification of the model the annealing period is considered constant at the reduced power.

Table 1 shows a list of different case studies (depicting different dispatch strategies) for which the simulation was performed. 1 sun solar irradiance has a constant value of $1000 \mathrm{~W} / \mathrm{m}^{2}$ and has a AM1.5 spectrum. Here 'normal sun' solar irradiance is defined as the standard hourly solar irradiance from the sun for a given location. Normal sun conditions vary over the day with real outdoor conditions. For all the above cases, the model was simulated at outdoor conditions and for various geographic locations for a year (February 1st, 2012- January 31st, 2013) in the U.S. to better understand real-world significance of this type of PVT system under different dispatch strategy. Four different cities, namely Goldendale (Klickitat county, Washington), San Antonio (Valles Caldera, New Mexico), Reno (UNR campus, Nevada) and Las Vegas (Southern Nevada) were chosen on the basis of different geographic features and climatic conditions to better analyze the effects of different dispatch strategies. The details for the locations are shown in Table 2 [39,40].

The solar irradiance, air temperature and soil temperature data was obtained on hourly basis for the four cities (Goldendale, San Antonio, Reno and Las Vegas) [36,37]. The average hourly solar irradiation data for the above mentioned cities were obtained using equation (4).

$S_{i=(1 t o 24)}=\frac{1}{366} \sum_{n=1}^{366} S_{i, n, c i t y}$

where, $S_{i}$ is the average solar irradiance for $i^{\text {th }}$ hour of four cities (averaged yearly), and $S_{i, n, c i t y}$ is the solar irradiance for $i^{\text {th }}$ hour and $n^{\text {th }}$ day for a year for a given location. Figure 3 shows the average hourly solar irradiance for the four cities obtained using equation (4). Average solar irradiance per day for Goldendale, San Antonio, Reno, and Las Vegas are 4.30, 4.96, 5.39, and 5.54 sun hours respectively. With hour 12 being the peak sun of the day the highest sun hour period is between hours 9 and 16 in the day when the solar irradiance is higher than $250 \mathrm{~W} / \mathrm{m}^{2}$. Therefore spike annealing is used between hours 8 and 15 as seen in Figure 3.

From equation (2) it can be seen that for c-Si-based PV cells more power is obtained at lower temperature with higher irradiance. In case of a-Si:H PV/T the effect of temperature and light intensity is more complicated as long time light exposure causes degradation and thermal annealing improves device performance by reducing defect states. As the exponential component of equation (3) represents the light induced degraded power therefore deriving a suitable dispatch strategy for a-Si:H PV/T will depend on the PV/T panel temperature, solar irradiance and peak sun hour period of a day. While taking into account the effects of SWE and annealing altogether the exponential component is required to be modified as a function of these parameters which requires further study. In order to determine the annealing effect a set of binary arrays were generated, which take into account the effects of dispatch strategies on hourly power generation. The binary values of these arrays were set based on specific dispatch strategies. The total energy generation over a year for the chosen cities for different operating temperature (i.e. $25{ }^{\circ} \mathrm{C}, 50{ }^{\circ} \mathrm{C}$ 
J. Rozario, A.H. Vora, S.K. Debnath, M.J.M. Pathak, J.M. Pearce, The effects of dispatch strategy on electrical performance of amorphous silicon-based solar photovoltaic-thermal systems, Renewable Energy 68, pp. 459-465 (2014). http://dx.doi.org/10.1016/j.renene.2014.02.029

and $90{ }^{\circ} \mathrm{C}$ ) which were obtained by using the hourly recorded standard solar irradiation data. A time period of 8784 hours (i.e. one year) with both 1 sun and normal sun solar irradiation was considered during the execution of the dispatch strategies. The total energy generated for each case over a year was determined to identify the most effective dispatch strategy for chosen geographical locations.

\section{Results and Discussions}

At higher temperatures a-Si:H-based solar cells degrade more rapidly initially, but stabilize at a higher power than when operated at lower temperatures [32]. Based on this knowledge, the available data, and temperature guided solar cell degradation principles a suitable equation is proposed which can approximately represent the experimental data. The curve fits for this approximation are shown in Figure 2, which represents the simulation output of dispatch strategy Case I (the control case). The study of Case II calculates the total energy generation over a year for the chosen cities for different operating temperature (i.e. $25^{\circ} \mathrm{C}, 50{ }^{\circ} \mathrm{C}$ and $90{ }^{\circ} \mathrm{C}$ ) which were obtained by using the hourly recorded standard solar irradiation data. A time period of 8784 hours (i.e. one year) with both 1 sun and normal sun solar irradiation was considered during the execution of the dispatch strategies explained in Case III to Case IX. The maximum power generated at different operating temperatures were normalized with respect to the initial maximum power (at $\mathrm{t}=0$ ) at reference temperature $25^{\circ} \mathrm{C}$ which has a value of approximately 5.3 $\mathrm{mW}$ for the small test cells. Case-III to Case-IX utilized an annealing operation. Both the values of 1 sun and normal sun energy generation were calculated for each case study.

Figure 4 shows the effect of annealing explained in Case III and degradation for the operating temperatures a) $25^{\circ} \mathrm{C}$, b) $50{ }^{\circ} \mathrm{C}$, and c) $90{ }^{\circ} \mathrm{C}$ respectively at 1 sun. In this case annealing is performed (from hour 8 to hour 9 ) once every two days (after the first day) followed by degradation at a definite operating temperature. Figure 4 shows that the cells generate more power with annealing. As can be seen from Figure 4 at lower temperatures (a and b) of operation SWE dominates and reduces electrical output as expected. In Figure 4c, operating at $90^{\circ} \mathrm{C}$ there is very little observable SWE as compared to the lower temperature cases.

Figure 5 shows the dispatch strategies individually for clarity. Figure 5 shows the 1 sun simulation results obtained for Case IV at operating temperatures a) $50{ }^{\circ} \mathrm{C}$ and b) $90{ }^{\circ} \mathrm{C}$. The annealing is performed once every day (from 800 to 900 hours) followed by a $50{ }^{\circ} \mathrm{C}$, and $90{ }^{\circ} \mathrm{C}$ degradation, resulted in greater output than the previous case.

The 1 sun simulation results for Case $\mathrm{V}$ at operating temperature $50{ }^{\circ} \mathrm{C}$ and $90{ }^{\circ} \mathrm{C}$ are shown in Figure 5c and d, respectfully. Annealing is performed twice every day. The interval between two consecutive annealing periods is four hours. Between the annealing cycles a degradation temperature of $50{ }^{\circ} \mathrm{C}$ and $90{ }^{\circ} \mathrm{C}$ is maintained respectively.

Figure 5e) and f) shows simulation results for Case VI. Annealing is performed three times a day with an interval of two hours. During the intervals a degradation temperature of 50 ${ }^{\circ} \mathrm{C}(\mathrm{e})$ and $90{ }^{\circ} \mathrm{C}$ (f) is maintained respectively

Similar plots were obtained for case studies VII, VIII, and IX. In all these cases simulations were performed for operating temperatures $25{ }^{\circ} \mathrm{C}, 50{ }^{\circ} \mathrm{C}$, and $90{ }^{\circ} \mathrm{C}$. Finally, area analysis was performed to determine the total energy generated in each cases. Figure 6 shows the 
J. Rozario, A.H. Vora, S.K. Debnath, M.J.M. Pathak, J.M. Pearce, The effects of dispatch strategy on electrical performance of amorphous silicon-based solar photovoltaic-thermal systems, Renewable Energy 68, pp. 459-465 (2014). http://dx.doi.org/10.1016/j.renene.2014.02.029

hourly maximum output power for different case studies at 1 sun and operating temperature 90 ${ }^{\circ} \mathrm{C}$.

To see how the dispatch strategies influence power throughout the day Figure 7 is used as an example and shows the average hourly power generation in San Antonio for different dispatch strategies. As can be seen in Figure 7, the power curves closely follow the solar irradiance curve shown on the right y-axis.

Figure 8 shows the total energy generation over a period of 8784 hours (under 1 sun and at different operating temperatures) with respect to the number of anneals per day. It is notable that at operating temperature $90{ }^{\circ} \mathrm{C}$ and 1 sun irradiance, the energy is maximized for the dispatch strategy of Case IV (annealing once per day). Beyond that at 1 sun irradiance, with increasing the number of anneals per day total energy generation decreases and even drops to lower values than the DSS energy. This can be attributed to the power drop during the annealing cycle. If too much of the day is spent annealing then there is not enough time to capture and convert radiation at the higher efficiencies. Also it is noteworthy that at operating temperatures $25{ }^{\circ} \mathrm{C}$ and $50^{\circ} \mathrm{C}$ the energy generation is not maximized for the strategy of Case IV. Instead, the energy is highest for Case $\mathrm{V}$ (annealing twice a day), which can be attributed to the fact that degradation is more pronounced at lower temperatures and the increased number of annealing cycles per day compensates for the loss. Figure 9 shows the total energy generation over a year (under normal sun for operating temperatures ) for a) $25{ }^{\circ} \mathrm{C}$, b) $50{ }^{\circ} \mathrm{C}$, and c) $90{ }^{\circ} \mathrm{C}$ for the four locations as a function of the number of anneals per day. Annealing once per day generated the maximum power. The lower values of energy than the 1 sun cases can be attributed to the reduced total flux as compared to constant 1 sun illumination. These results show that annealing once a day is sufficient to maximize electrical energy generation using spike annealing in a-Si:H PVT.

Table 3 shows the simulated normalized energy generation over a year for the four cities. All the values were normalized with respect to the no annealing energy generation at corresponding operating temperatures. Case Study-IV (annealing once per day) was found to be the most effective dispatch strategy; resulting in more than $23 \%, 10 \%$, and $1.2 \%$ additional energy generation over a year for the operating temperatures $25^{\circ} \mathrm{C}, 50{ }^{\circ} \mathrm{C}$, and $90{ }^{\circ} \mathrm{C}$ respectively while the total energy generation is maximum for operating temperature $90^{\circ} \mathrm{C}$. These values are in agreement with past work [34] that predicted about a 10\% improvement using only 1 sun degradation and daily spike anneals at $50^{\circ} \mathrm{C}$. The results also underscore the importance of using real temperatures and not STC in the optimization of PV devices. Although, using Case IV at 25 ${ }^{\circ} \mathrm{C}$ showed more than a 23\% increase in output in most locations the operating temperatures for $\mathrm{PV}$ are much higher. It is also clear that running a-Si:H PV/T at high temperatures (e.g. $90{ }^{\circ} \mathrm{C}$ ) negated the majority of the spike annealing benefit - gaining only about $1 \%$. At all temperatures, one time annealing per day during peak sun hours is sufficient to generate maximum power in all of the geographic locations simulated. Geographic location (at least within the contiguous United States) does not appear to be an important variable for determining the optimum dispatch strategy for the electrical output of spike annealing a-Si:H PV/T devices as the range in solar flux was not enough to appreciably effect the dispatch strategy for annealing. In general the operating temperature for solar cells can be easily raised to $50^{\circ} \mathrm{C}$, but using the thermal collector it is possible to maintain a steady temperature of $90^{\circ} \mathrm{C}$ which provides more higher energy.

Now that a suitable dispatch strategy has been developed future work is needed to determine the degradation characteristics at temperatures other than $25{ }^{\circ} \mathrm{C}, 50{ }^{\circ} \mathrm{C}$, and $90{ }^{\circ} \mathrm{C}$. 
Using equation (3) it is possible to obtain the degradation traits at other temperatures, but the problem lies on determining the accurate values of the parameters $k_{d s s}$ and $u_{d s s}$ as these parameters are function of the PV/T temperature. In such a case the values can be approximated (e.g. if at temperatures $T_{1}$ and $T_{2}\left(T_{1}<T_{2}\right)$ the values of parameter $k_{d s s}$ are $k_{d s s 1}$ and $k_{d s s 2}$ respectively, then at a temperature $T_{x}$ such that $T_{1}<T_{x}<T_{2}$ the value of $k_{d s s}$ ) using:

$k_{d s s x}=k_{d s s 1}+\frac{\left(k_{d s s 2}-k_{d s s 1}\right)}{\left(T_{2}-T_{1}\right)} \times\left(T_{x}-T_{1}\right)$

Similarly the equation for getting $u_{d s s x}$ is following,

$u_{d s s x}=u_{d s s 1}+\frac{\left(u_{d s s 2}-u_{d s s 1}\right)}{\left(T_{2}-T_{1}\right)} \times\left(T_{x}-T_{1}\right)$

Using equation (5) and (6) it is possible to determine the approximate values of $k_{d s s}$ and $u_{d s s}$ for a an arbitrary operating temperature. Future research can focus on experiments that could help reduce the error associated with this approximation by using actual field temperatures. In addition, the positive results found in the simulations, indicate that future work should be undertaken to verify the energy gains using a-Si:H PV/T with daily annealing pulses and to find the optimal operating temperature to maximize electrical output. Finally, further work is necessary to maximize the total exergy of the system [41], by considering the effects of annealing pulses on the thermal energy recovered from the PV/T and a final optimal dispatch strategy can be determined taking into account load data for a specific application and location.

\section{Conclusions}

Amorphous silicon based solar cells have a lower thermal coefficient, but their performance is undermined by the fact that long time light exposure causes formation of defect states that reduces power generation. Fortunately, a-Si:H also has the ability to reduce the quantity of defect states with exposure to high temperature annealing pulses. This property makes them more suitable for PV/T application where the thermal collector temperature can be easily raised to the annealing temperature. The results of this study, which investigated the impact of annealing cycles and geographic locations with real solar flux data showed that at standard PV operating temperatures one anneal pulse per day provided the largest electrical output through the year. The results showed that significant amount of additional energy generation is possible over the year with an appropriate dispatch strategy and operating temperature providing 23\%, $10 \%$, and $1.2 \%$ additional energy generation over a year for the operating temperatures $25{ }^{\circ} \mathrm{C}, 50{ }^{\circ} \mathrm{C}$, and $90^{\circ} \mathrm{C}$ respectively. Further study of annealing cycles and analysis of the degradation at other operating temperatures coupled with the optimization of the thermal component of the PV/T can provide the optimal dispatch strategy for the devices for any application.

\section{Acknowledgements}

This work was supported by the Winn Fellowship, Natural Sciences and Engineering Research Council of Canada, Canada Foundation for Innovation, Ministry of Research and Innovation, the 
J. Rozario, A.H. Vora, S.K. Debnath, M.J.M. Pathak, J.M. Pearce, The effects of dispatch strategy on electrical performance of amorphous silicon-based solar photovoltaic-thermal systems, Renewable Energy 68, pp. 459-465 (2014). http://dx.doi.org/10.1016/j.renene.2014.02.029

Canadian Solar Building Network, and PV Measurements Inc. The authors would like to acknowledge K. Girotra for providing samples and S. Harrison for helpful discussions.

\section{References}

[1] K. Branker, M. J.M. Pathak, J. M. Pearce, A Review of Solar Photovoltaic Levelized Cost of Electricity, Renewable \& Sustainable Energy Reviews 15 (2011) 4470-4482. DOI: 10.1016/j.rser.2011.07.104

[2] T. T. Chow, A review on photovoltaic/thermal hybrid solar technology, Applied Energy 87 (2010) 365-379. DOI: 10.1016/j.apenergy.2009.06.037

[3] Y. Tripanagnostopoulos, T. Nousia, M. Souliotis, P. Yianoulis, Hybrid Photovoltaic/Thermal Solar Systems, Solar Energy 72 (2002) 217-234. DOI: 10.1016/S0038-092X(01)00096-2

[4] B. J. Huang, T. H. Lin, W. C. Hung, F. S. Sun, Performance evaluation of solar photovoltaic/thermal systems, Solar Energy 70 (2001) 443-448. DOI: 10.1016/S0038$\underline{092 X(00) 00153-5}$

[5] P. Derewonko and J. M. Pearce, Optimizing design of household scale hybrid solar photovoltaic + combined heat and power systems for Ontario, in: 34th Proceedings of IEEE Photovoltaic Specialists Conference (PVSC), 2009, pp. 001274-001279. DOI: 10.1109/PVSC.2009.5411247

[6] Y. B. Assoa, C. Menezo, G. Fraisse, R. Yezou, and J. Brau, Study of a new concept of photovoltaic-thermal hybrid collector, Solar Energy 81 (2007) 1132-1143. DOI: 10.1016/j.solener.2007.04.001

[7] Y. V. Vorobiev, J. Gonzalez-Hernandez, and A. Kribus, Analysis of potential conversion efficiency of a solar hybrid system with high-temperature stage, J. Sol. Energ. Eng. 128 (2006) 258-260. DOI: 10.1016/j.solener.2005.04.022

[8] S. A. Kalogirou and Y. Tripanagnostopoulos, Hybrid PV/T solar systems for domestic hot water and electricity production, Energ. Convers. Manage., 47 (2006) 3368-3382. DOI: 10.1016/j.enconman.2006.01.012

[9] R. K. Jardan, I. Nagy, A. Cid-Pastor, R. Leyva, A. El Aroudi, and L. Martinez-Salamero, Combined Photovoltaic / Thermal Energy System for Stand-alone Operation, in: Proceedings of IEEE International Symposium on Industrial Electronics, 2007, pp. 24032408. DOI: 10.1109/ISIE.2007.4374983

[10] A. Virtuani, D. Pavanello, G.Friesen. Overview of temperature coefficients of different thin film photovoltaic technologies. In 25th European Photovoltaic Solar Energy Conference and Exhibition/5th World Conference on Photovoltaic Energy Conversion, 2010, pp. 6-10.

[11] P. Wormser, S. Strong, Evaluation of the potential for use of new thin film photovoltaic materials as selective surfaces for solar thermal absorbers in flat-plate combined photovoltaic/thermal collectors, ASHRAE Final Report \#1109-RP, 2006, pp. 1-23.

[12] E. Schweizer, A.G. Enecolo, LESO-PB, New generation of hybrid solar PV/T collectors. Final Report DIS 56360/16868, 2000, pp. 1-55. 
J. Rozario, A.H. Vora, S.K. Debnath, M.J.M. Pathak, J.M. Pearce, The effects of dispatch strategy on electrical performance of amorphous silicon-based solar photovoltaic-thermal systems, Renewable Energy 68, pp. 459-465 (2014). http://dx.doi.org/10.1016/j.renene.2014.02.029

[13] G. Fraisse, C. Ménézo, K. Johannes, Energy performance of water hybrid PV/T collectors applied to combisystems of Direct Solar Floor type, Solar Energy, 81 (2007) 1426-1438. DOI: 10.1016/j.solener.2006.11.017

[14] H. A. Zondag, D. W. de Vries, W. G. J. van Helden, R. J. C. van Zolingen, A. A. van Steenhoven, The yield of different combined PV-thermal collector designs, Solar Energy, 74 (2003) 253-269. DOI: 10.1016/S0038-092X(03)00121-X

[15] Y. Vorobiev, J. González-Hernández, P. Vorobiev, L. Bulat, Thermal-photovoltaic solar hybrid system for efficient solar energy conversion, Solar Energy, 80 ( 2006) 170-176. DOI: 10.1016/j.solener.2005.04.022

[16] C. R. Wronski, J. M. Pearce, J. Deng, V. Vlahos, R. W. Collins, Intrinsic and light induced gap states in a-Si:H materials and solar cells - effects of microstructure, Thin Solid Films, 451-452 (2004) 470-475. DOI: 10.1016/j.tsf.2003.10.129

[17] D. L. Staebler, C. R. Wronski, Reversible conductivity changes in discharge-produced amorphous Si, Appl. Phys. Lett., 31 (1977) 292-294. DOI: 10.1063/1.89674

[18] H. Fritzsche, Development in understanding and controlling the Staebler-Wronski effect in a-Si:H, Annual Reviews Materials Resarch, 31 (2001) 47-79.

[19] J. Deng, M.L. Albert, J.M. Pearce, R.W. Collins, C.R. Wronski, The nature of native and light induced defect states in i-layers of high quality a-Si:H solar cells derived from dark forward bias current-voltage characteristics, Materials Research Society Symposium Proceedings 862 (2005) A11.4. DOI: 10.1557/PROC-862-A11.4.

[20] A. Klaver, R. A. C. M. M. van Swaaij, Modeling of light-induced degradation of amorphous silicon solar cells, Solar Energy Materials and Solar Cells, 92 (2008) 50-60. DOI: 10.1016/j.solmat.2007.08.010

[21] J. M. Pearce, J. Deng, M. L. Albert, C. R. Wronski, R. W. Collins, Room temperature annealing of fast state from 1 sun illumination in protocrystalline Si:H materials and solar cells, in: 31st IEEE Photovoltaic Specialists Conference Proceedings of , 2005, pp. 15361539. DOI: $10.1109 / P V S C .2005 .1488436$

[22] C. R. Wronski, J. M. Pearce, R. J. Koval, X. Niu, A. S. Ferlauto, J. Koh, R. W. Collins, Light induced defect creation kinetics in thin film protocrystalline silicon materials and their solar cells, in: Materials Research Society Symposium Proceedings 715 (2002) A13.4, DOI: 10.1557/PROC-715-A13.4.

[23] S. Fujikake, H. Ota, M. Ohsawa, T. Hama, Y. Ichikawa, H. Sakai, Light-induced recovery of a-Si solar cells, Solar Energy Materials and Solar Cells 34 (1994) 449-454. DOI: 10.1016/0927-0248(94)90072-8

[24] M.L. Albert, J. Deng, X..Niu, J.M. Pearce, R.W. Collins, C.R. Wronski, The creation and relaxation kinetics of light induced defects in a-Si:H located at different energies in the gap, Materials Research Society Symposium Proceedings 862 (2005) A13.2, DOI: 10.1557/PROC-862-A13.2.

[25] I. Pola, D. Chianese, L. Fanni, R. Radel, Analysis of annealing and degradation effects on aSi modules Source; in: Proceedings of the 23rd European Photovoltaic Solar Energy Conference and Exhibition, 1-5 September 2008, Valencia, Spain, pp. 2301-2304.

[26] C.R. Wronski, J.M. Pearce, J. Deng, V. Vlahos, R.W. Collins, Intrinsic and light induced gap states in a-Si:H materials and solar cells—effects of microstructure, Thin Solid Films 451-452 (2004) 470-475. DOI: 10.1016/j.tsf.2003.10.129 
J. Rozario, A.H. Vora, S.K. Debnath, M.J.M. Pathak, J.M. Pearce, The effects of dispatch strategy on electrical performance of amorphous silicon-based solar photovoltaic-thermal systems, Renewable Energy 68, pp. 459-465 (2014). http://dx.doi.org/10.1016/j.renene.2014.02.029

[27] J. M. Pearce, J. Deng, R. W. Collins, and C. R. Wronski, Light-induced defect states in hydrogenated amorphous silicon centered around 1.0 and $1.2 \mathrm{eV}$ from the conduction band edge, Appl. Phys. Lett., vol. 83, no. 18, pp. 3725-3727 (2003). DOI: 10.1063/1.1624637

[28] J. Pearce, X. Niu, R. Koval, G. Ganguly, D. Carlson, R.W. Collins, C.R. Wronski, Contributions of DO and non-DO gap states to the kinetics of light induced degradation of amorphous silicon under 1 sun illumination, Materials Research Society Symposium Proceedings 664 (2001) A12.3. DOI: 10.1557/PROC-664-A12.3.

[29] R. Ruther, G. Tamizh-Mani, J. del Cueto, J. Adelstein, M. M. Dacoregio, B. von Roedern, Performance test of amorphous silicon modules in different climates - year three: higher minimum operating temperatures lead to higher performance levels, in: 31st IEEE Photovoltaic Specialists Conference Proceedings, 2005, pp. 1635- 1638. DOI: 10.1109/PVSC.2005.1488459

[30] S. Kalogirou, The potential of solar industrial process heat applications, Applied Energy 76 (2003) 337-361. DOI: 10.1016/S0306-2619(02)00176-9

[31] P. Mahtani, N.P. Kherani, S. Zukotynski, The use of amorphous silicon in fabricating a photovoltaic-thermal system, in: Proceedings of the second Canadian Solar Buildings Conference, 2007, pp. 1-4.

[32] M.J.M Pathak, K. Girotra, S.J. Harrison and J.M. Pearce, The effect of hybrid photovoltaic thermal device operating conditions on intrinsic layer thickness optimization of hydrogenated amorphous silicon solar cells, Solar Energy 86, (2012) 2673-2677. DOI:10.1016/j.solener.2012.06.002

[33] S.A. Kalogiru, Y. Tripanagnostopoulos, Industrial application of PV/T solar energy systems, Applied Thermal Engineering 27 (2007) 1259-1270. DOI: 10.1016/j.applthermaleng.2006.11.003

[34] M. J. M. Pathak, J. M. Pearce, S. J. Harrison, Effects on amorphous silicon photovoltaic performance from high-temperature annealing pulses in photovoltaic thermal hybrid devices, Solar Energy Materials and Solar Cells, 100 (2012) 199-203. DOI: 10.1016/j.solmat.2012.01.015

[35] A. J Anderson, Photovoltaic translation equations: A new approach, Final subcontract report, NREL Technical Report \# NREL/TP--411-20279, 1996 Jan 01, DOI: $10.2172 / 177401$

[36] D. L. King, J. A. Kratochvil, W. E. Boyson, Temperature coefficients for PV modules and arrays: measurement methods, difficulties, and results, in: 26th IEEE Photovoltaic Specialists Conference Proceedings, 1997, pp. 1183-1186. DOI: 10.1109/PVSC.1997.654300

[37] M. Shima, M. Isomura, K. Wakisaka, K. Murata, M. Tanaka, The influence of operation temperature on the output properties of amorphous silicon-related solar cells. Solar Energy Materials and Solar Cells, 85 (2005) 167-175.DOI: 10.1016/j.solmat.2004.04.016

[38] L. Yang, L. Chen, Thickness dependence of light induced degradation in a-Si:H solar cells, Journal of Non-Crystalline Solids 137-138 (1991) 1189-1192. DOI: $\underline{10.1016 / S 0022-}$ 3093(05)80336-9

[39] AgriMet - The Pacific Northwest Cooperative Agricultural Weather Network, Bureau of Reclamation, <http://www.usbr.gov/pn/agrimet/>, 2013.

[40] Western Regional Climate Center - Desert Research Institute - Reno, Nevada, $<$ http://www.wrcc.dri.edu/weather/index.html>, 2013. 
J. Rozario, A.H. Vora, S.K. Debnath, M.J.M. Pathak, J.M. Pearce, The effects of dispatch strategy on electrical performance of amorphous silicon-based solar photovoltaic-thermal systems, Renewable Energy 68, pp. 459-465 (2014). http://dx.doi.org/10.1016/j.renene.2014.02.029

[41] M. J. M. Pathak, P. G. Sanders, J. M. Pearce, Optimizing Limited Solar Roof Access by Exergy Analysis of Solar Thermal, Photovoltaic, and Hybrid Photovoltaic Thermal Systems (to be published).

Figure Captions

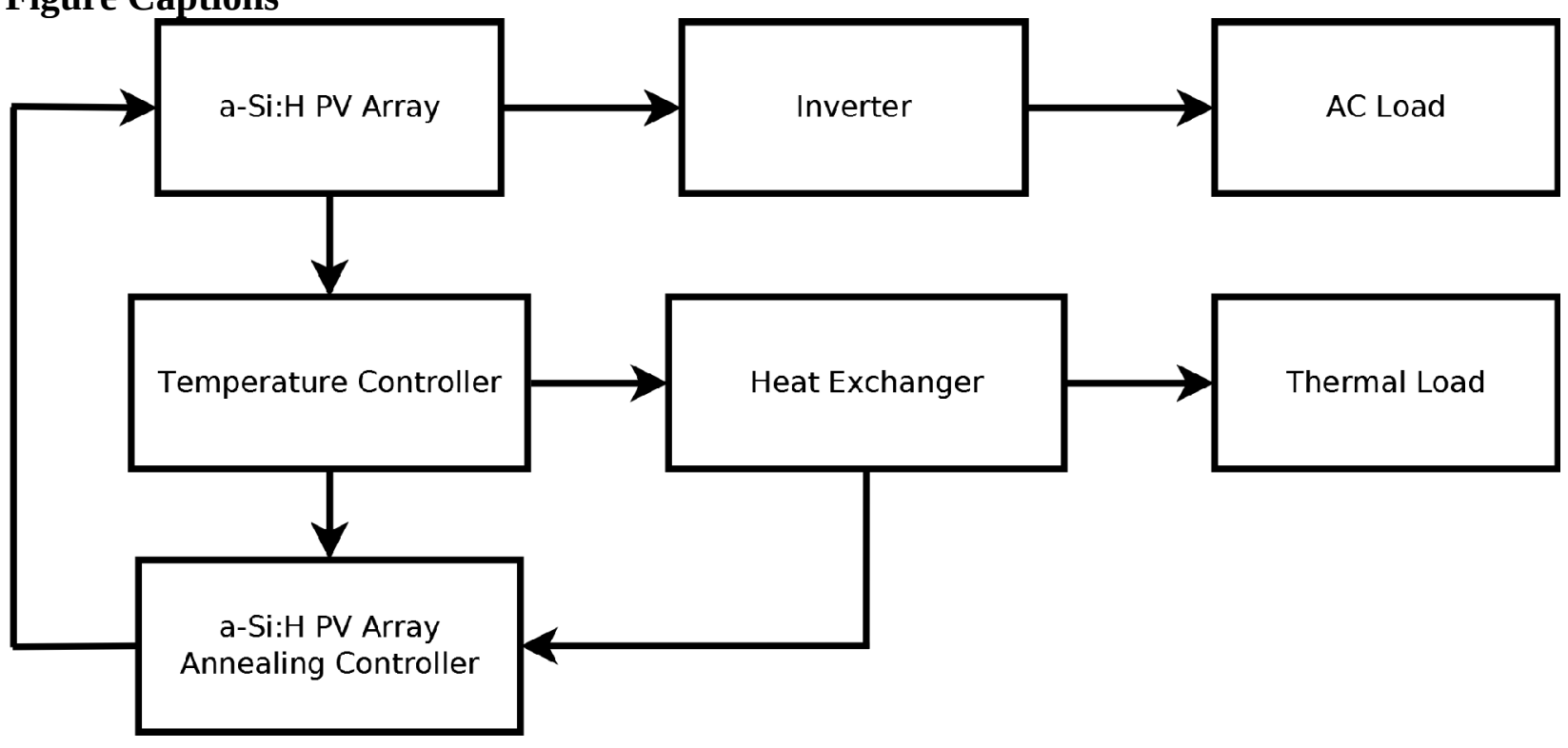

Figure 1. Schematic of a-Si:H-based PVT system.

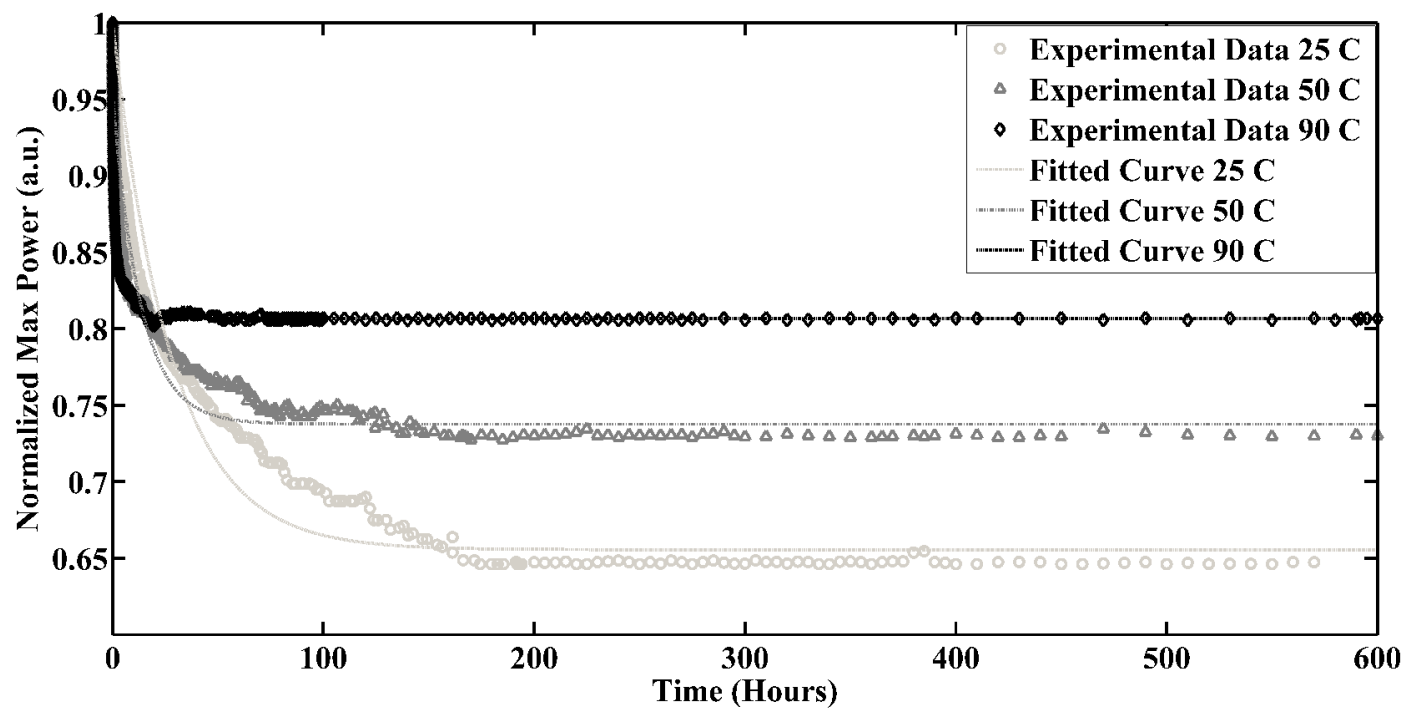

Figure 2. Experimental data showing degenerated steady state obtained at temperatures $25{ }^{\circ} \mathrm{C}, 50$ ${ }^{\circ} \mathrm{C}$, and $90{ }^{\circ} \mathrm{C}$ respectively for a-Si:H PV cell active layer thickness of $630 \mathrm{~nm}$ under 1 sun [34] and exponential fits using equation (3). 
J. Rozario, A.H. Vora, S.K. Debnath, M.J.M. Pathak, J.M. Pearce, The effects of dispatch strategy on electrical performance of amorphous silicon-based solar photovoltaic-thermal systems, Renewable Energy 68, pp. 459-465 (2014). http://dx.doi.org/10.1016/j.renene.2014.02.029

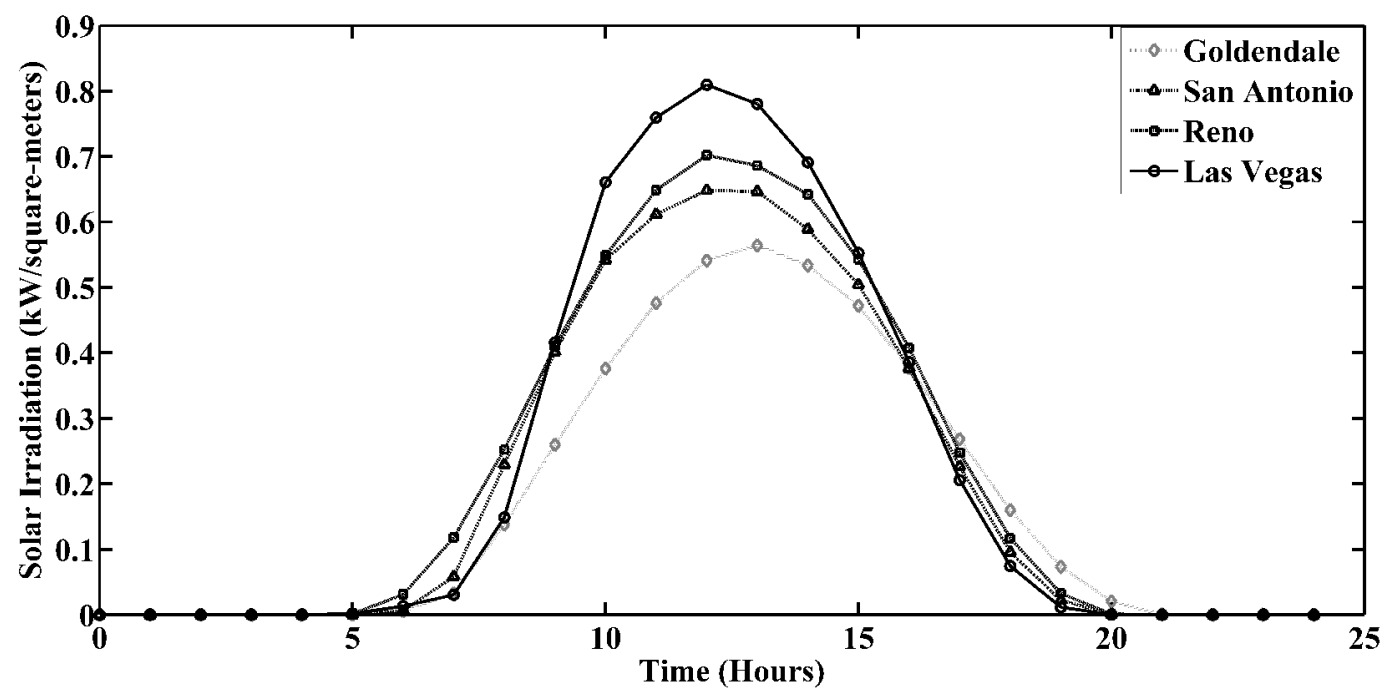

Figure 3: Average hourly solar irradiance for the four cities for whole year (February 1st, 2012January 31st, 2013).

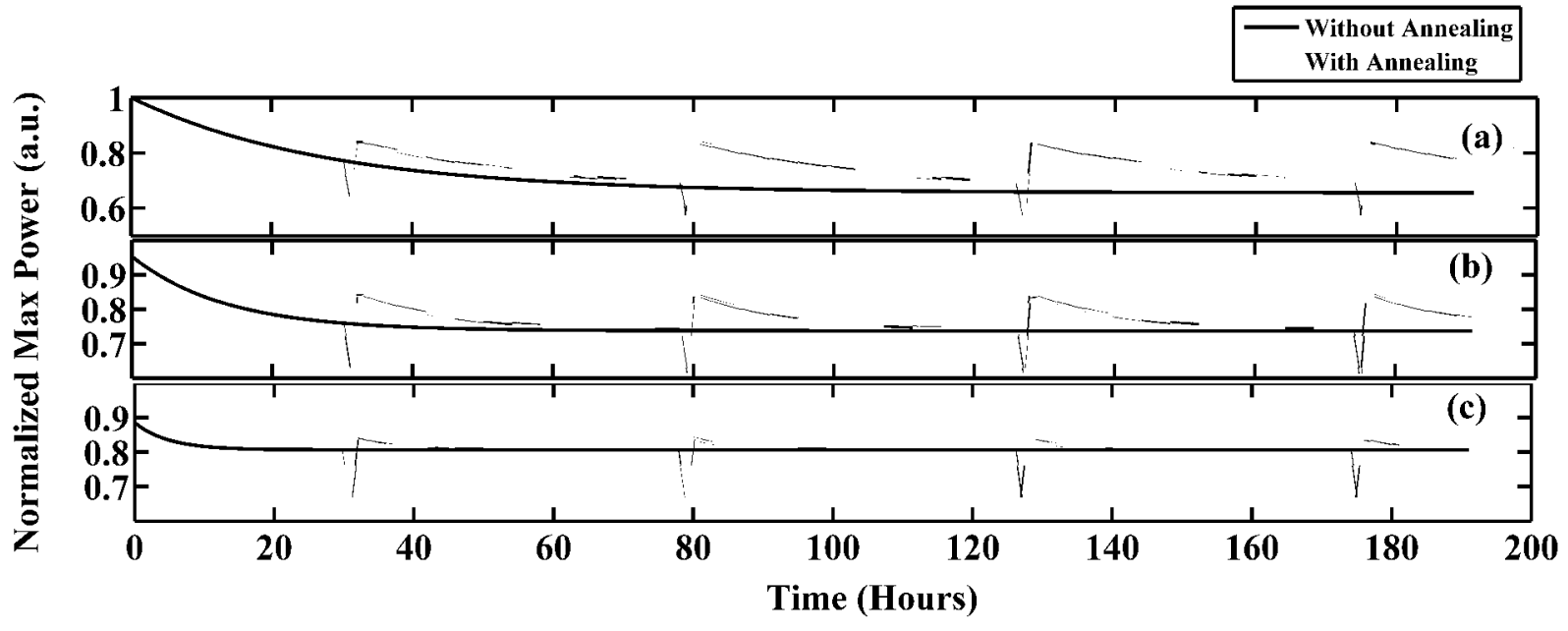

Figure 4: Figure 4 Dispatch strategy Case-III : annealing once every other day, for the operating temperatures a) $25{ }^{\circ} \mathrm{C}$, b) $50{ }^{\circ} \mathrm{C}$, and c) $90{ }^{\circ} \mathrm{C}$ at 1 sun. 


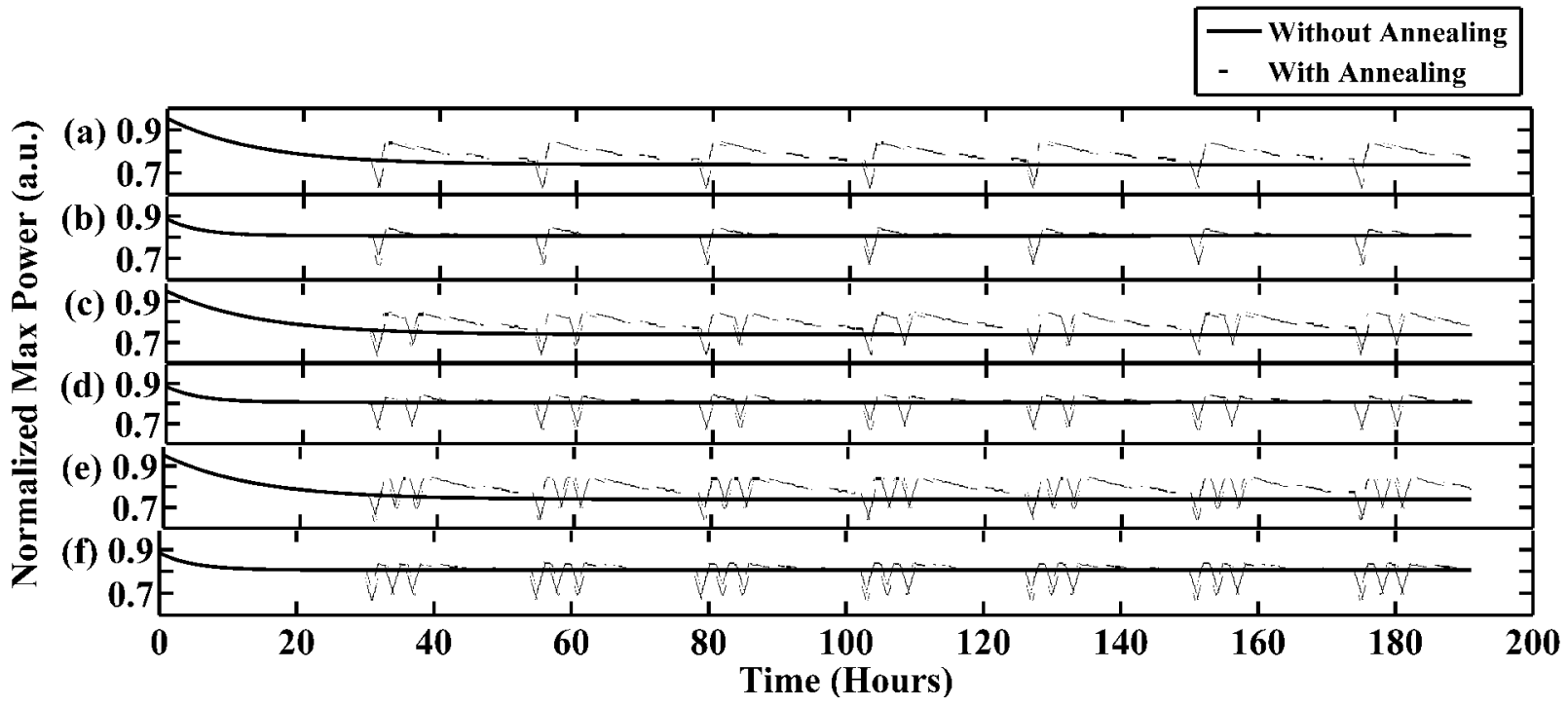

Figure 5: Dispatch strategies consisting of Case-III :annealing once every day, under 1 sun, a) $50{ }^{\circ} \mathrm{C}$ degradation and b) $90{ }^{\circ} \mathrm{C}$ degradation. Dispatch Strategy Case-V : annealing twice every day, under 1 sun, c) $50{ }^{\circ} \mathrm{C}$ and d) $90{ }^{\circ} \mathrm{C}$ degradation. Dispatch Strategy Case-VI : annealing three times every day, under 1 sun, e) $50^{\circ} \mathrm{C}$ and f) Dispatch Strategy Case-V ; annealing three times every day, under 1 sun, $90^{\circ} \mathrm{C}$ degradation.

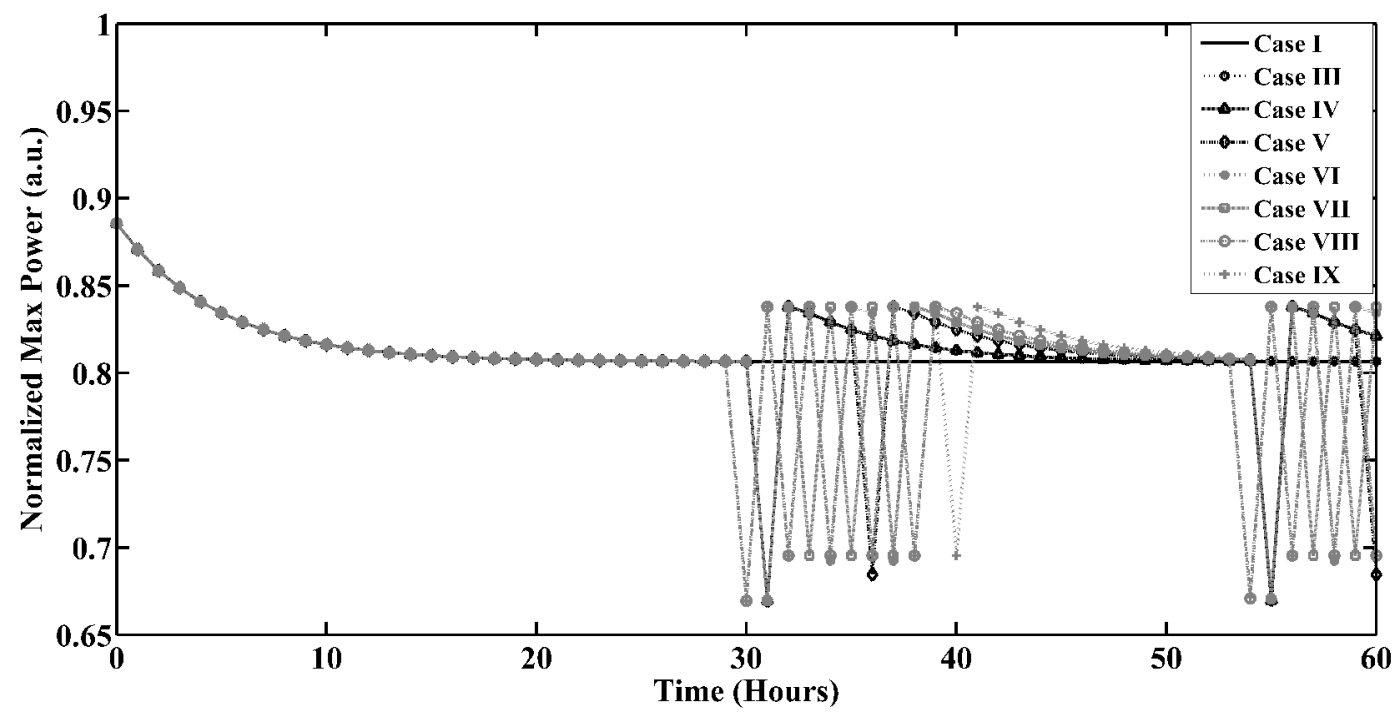

Figure 6: Hourly maximum output power for different dispatch strategies under 1 sun (operating temperature $90^{\circ} \mathrm{C}$ ). 


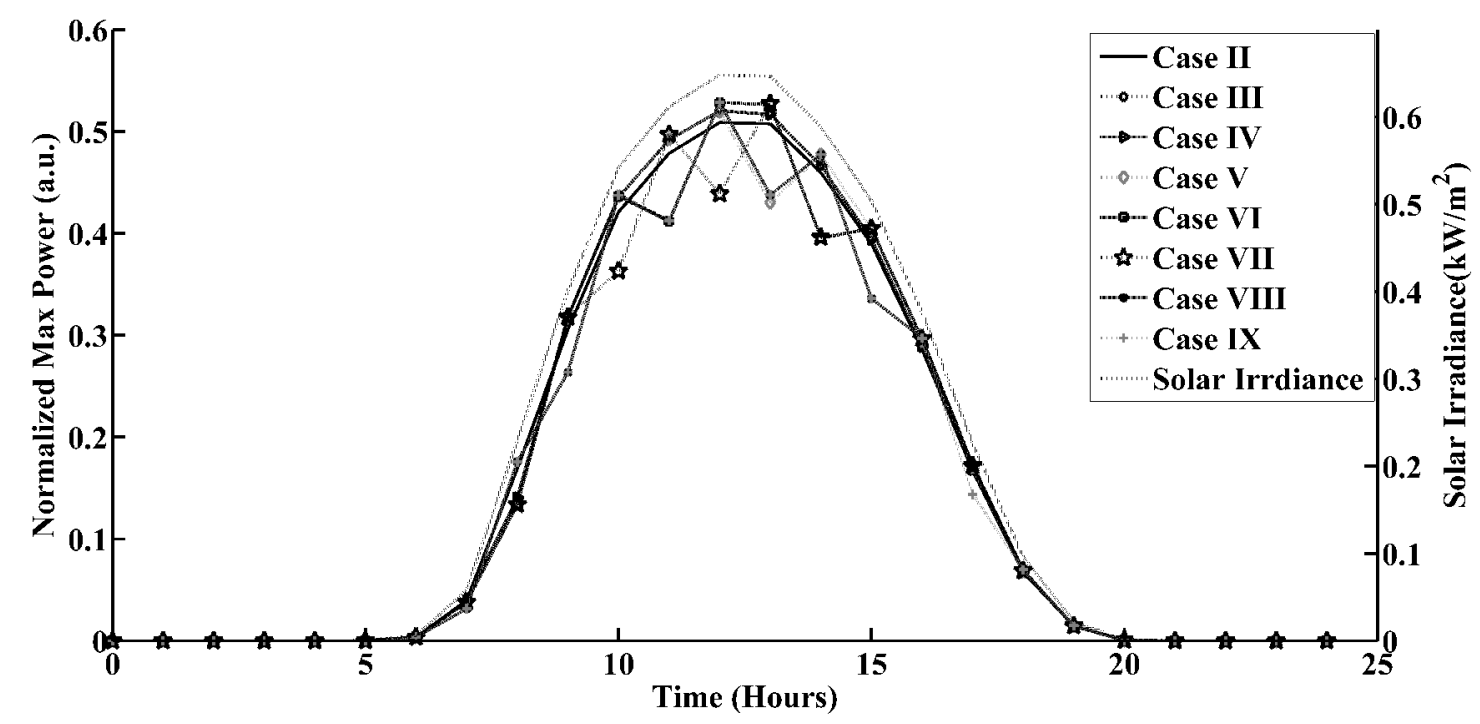

Figure 7: Average hourly power generation in San Antonio for different case studies. Right Yaxis shows average hourly solar irradiance.

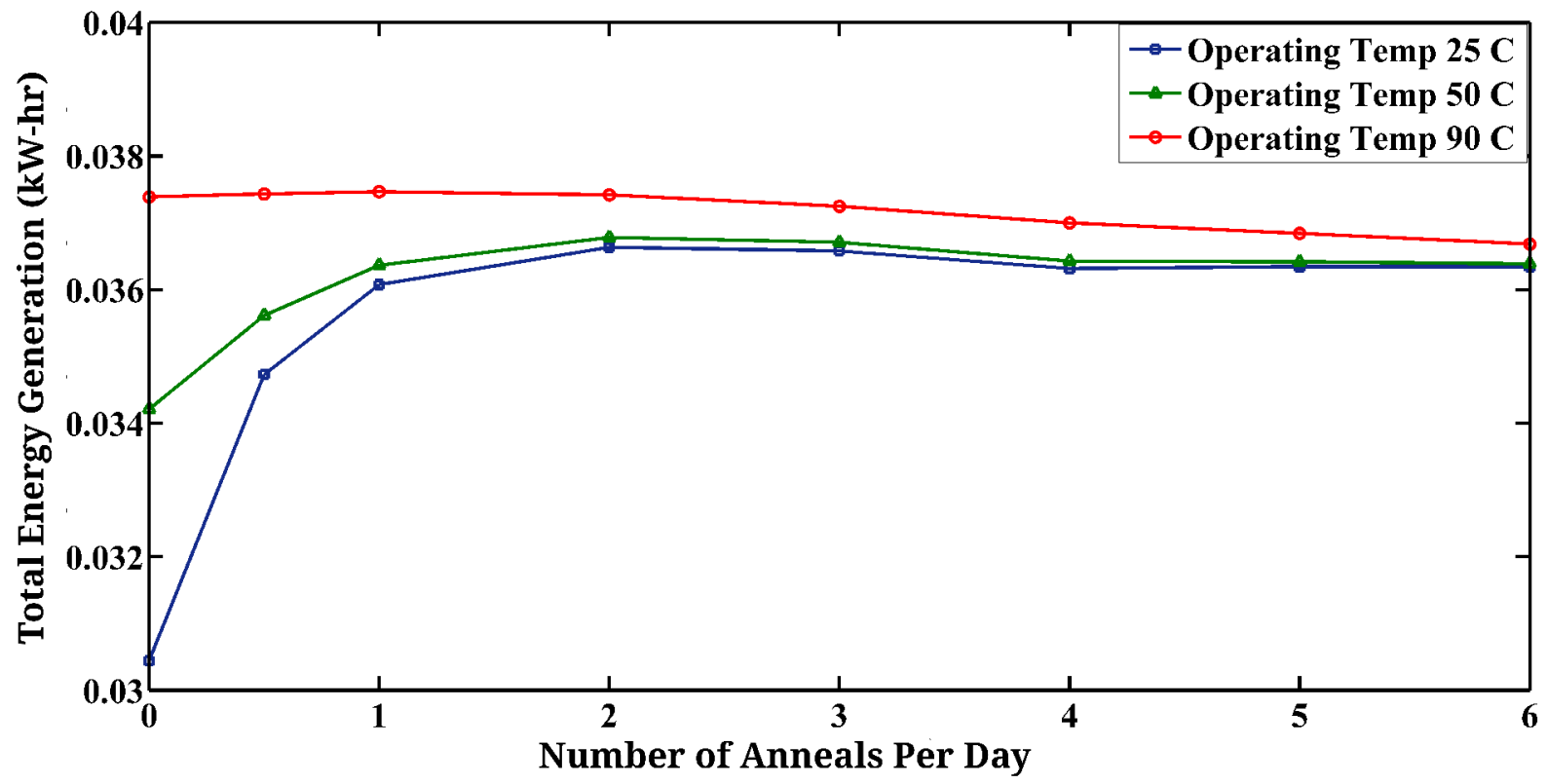

Figure 8: Total energy generation (at operating temperature $25^{\circ} \mathrm{C}, 50^{\circ} \mathrm{C}$, and $90{ }^{\circ} \mathrm{C}$ under 1 sun) over a time period of 8784 hours as a function of the number of anneals per day. 
J. Rozario, A.H. Vora, S.K. Debnath, M.J.M. Pathak, J.M. Pearce, The effects of dispatch strategy on electrical performance of amorphous silicon-based solar photovoltaic-thermal systems, Renewable Energy 68, pp. 459-465 (2014). http://dx.doi.org/10.1016/j.renene.2014.02.029

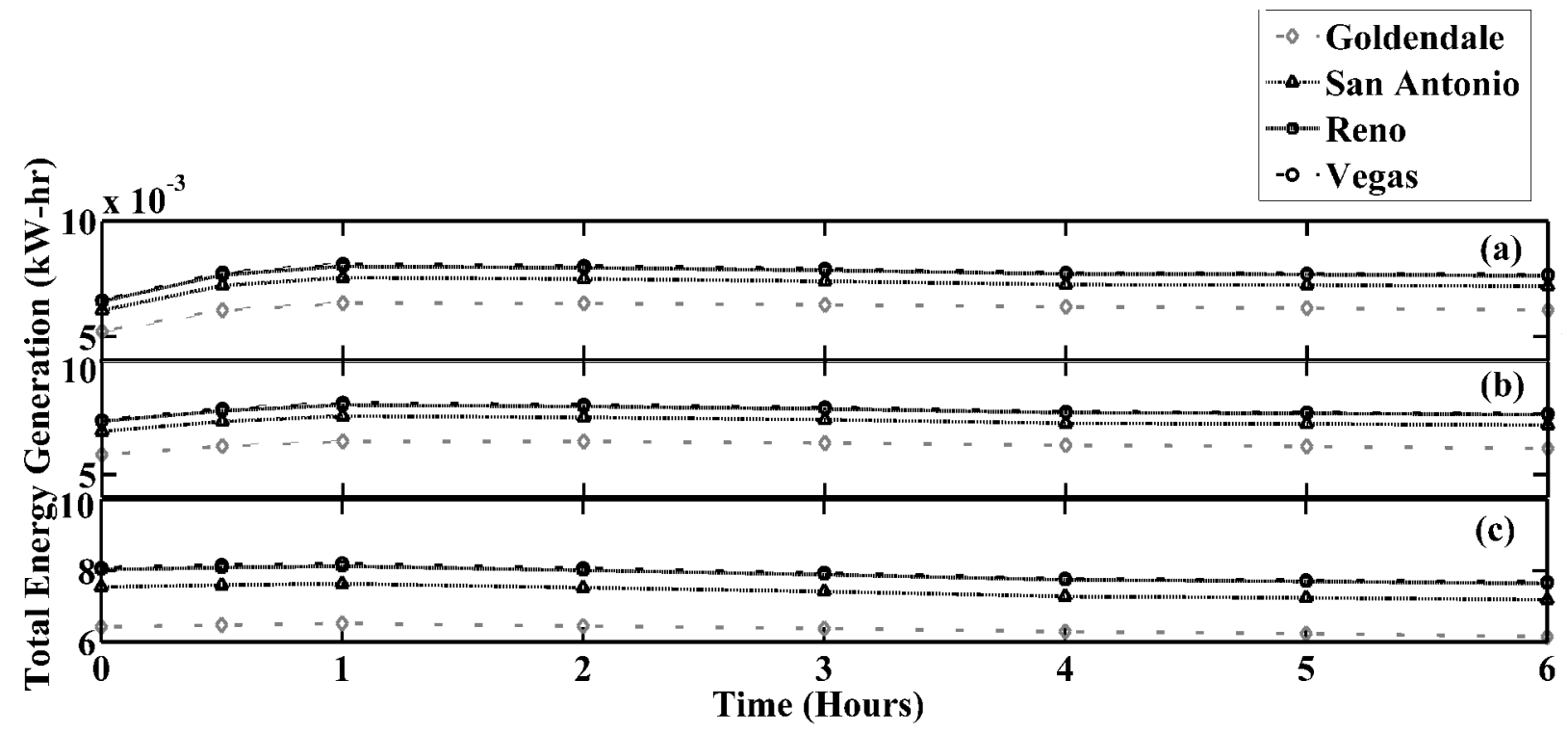

Figure 9: Total energy generation under normal sun at operating temperature for a) $25^{\circ} \mathrm{C}$, b) 50 ${ }^{\circ} \mathrm{C}$, and c) $90{ }^{\circ} \mathrm{C}$ for the four cities over a year with change in number of anneals per day. 